\title{
Femtomole per Gram
}

National Cancer Institute

\section{Source}

National Cancer Institute. Femtomole per Gram. NCI Thesaurus. Code C73711.

A molality unit that describes the amount of substance, expressed in femtomole(s) per gram. 